\title{
Design Sprint dalam Kuliah: Eksplorasi Metode Pembelajaran Baru pada Mata Kuliah Design Thinking
}

\author{
Ryan P. Sutanto \\ Program Studi Desain Komunikasi Visual, Fakultas Seni dan Desain \\ Universitas Kristen Petra, Jl. Siwalankerto No.121-131, Surabaya \\ E-mail: ryan@petra.ac.id
}

\begin{abstract}
Abstrak
Teori Design Thinking umumnya diajarkan dalam kelas berbasis proyek. Di sisi lain, ada metode baru yang sejalan dengan teori design thinking, yaitu: Design Sprint. Penggunaan design sprint tidak hanya bisa diaplikasikan dalam perusahaan perintis namun juga bisa diajarkan kepada mahasiswa untuk menambah wawasan dan pengetahuan mahasiswa melalui praktik. Sebagai sebuah metode yang berbasiskan kerja sama dalam sebuah tim, design sprint mendorong mahasiswa untuk mengembangkan sikap kolaboratif dalam menyelesaikan sebuah permasalahan. Design sprint secara daring menjadi lebih kompleks untuk digunakan dalam kelas. Persiapan yang matang menjadi kunci sebuah design sprint yang sukses dan lancar.
\end{abstract}

Kata kunci: Design sprint, daring, edukasi, design thinking.

\begin{abstract}
Design thinking theory is usually taught in a project-based learning classroom/course. There is a new learning method that is relevant to design thinking, which is design sprint. A design sprint is not only applicable to users in the technology and start-up industry but can be taught to students. This practice will enhance students' knowledge and understanding through practice. A design sprint is a highly collaborative method that pushes students to collaborate with their peers to solve a design challenge. Doing a design sprint on an online course can be tricky, therefore good preparation is a key success to a successful design sprint.
\end{abstract}

Keywords: Design sprint, online, education, design thinking.

\section{Pendahuluan}

Design Thinking dipahami sebagai proses berpikir strategis untuk menciptakan ide awal dalam pengembangan solusi menggunakan prinsip desain, hingga terciptanya solusi desain (Canedo \& Ferreira, 2019). Umumnya teori design thinking diaplikasikan dalam sebuah kelas desain komunikasi visual dengan pendekatan pembelajaran berbasis proyek. Pembelajaran berbasis proyek bukanlah pembelajaran yang kohesif. Ada banyak pendekatan dengan gaya sendiri untuk pembelajaran ini, yang sangat berbeda satu sama lain (Canedo \& Ferreira, 2019).

Design Sprint adalah metode untuk mengatasi permasalahan dalam jangka panjang atau pendek, yang dikembangkan oleh Jake Knapp dan rekan-rekannya di Google Ventures.
Design sprint merupakan metode yang cukup baru di dunia desain dan banyak dipakai, terutama pada perusahaan rintisan dan industri teknologi. Design sprint biasanya melibatkan 5 hari kerja dari Senin hingga Jumat. Bekerja bersama dalam design sprint, dapat mempersingkat siklus debat tanpa akhir dan memampatkan waktu berbulan-bulan menjadi satu minggu (Knapp, Jake, 2019). Design sprint adalah proses yang direncanakan dengan baik, terdiri dari langkah dan alat untuk mendapatkan solusi kreatif dan mengujinya kepada pengguna. Design Sprint berfokus pada menghasilkan ide, membuat/belajar dari iterasi desain awal, dan menghasilkan ide baru untuk membuat iterasi desain berikutnya. Berbeda dengan proses desain biasanya, daripada membangun atau merilis produk / layanan tanpa pengujian, design sprint berfokus pada inti dari masalah itu sendiri. 


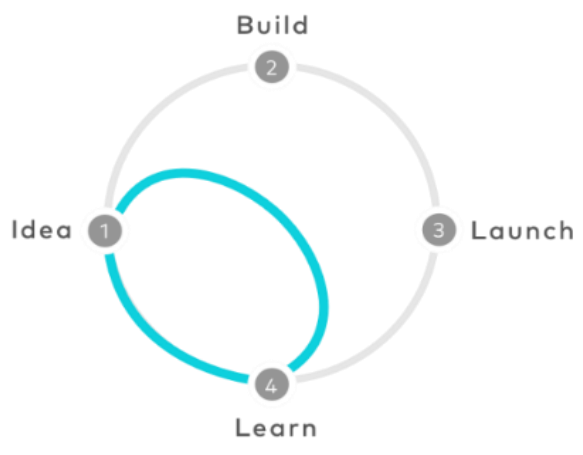

Gambar 1. Diagram Design Sprint

Sumber: https://www.gv.com/sprint/

Metode design sprint kemudian adaptasi dalam kelas Design Thinking. Adanya kesamaan metode design sprint dengan teori design thinking, membuat metode ini cocok untuk diadaptasi dalam kelas pembelajaran berbasis proyek. Baik metode design sprint dan teori design thinking memiliki proses yang sama, dimulai dari memahami user, proses pencarian ide, pembuatan purwarupa dan testing. Design sprint memberikan kerangka kerja bagi teori design thinking dengan menyediakan langkahlangkah detail dalam setiap fase desain. Kondisi perkuliahan daring membawa tantangan tersendiri bagi peserta design sprint dan dosen mata kuliah sebagai fasilitator design sprint.

Pembelajaran ini diharapkan dapat mensimulasikan teori design thinking yang biasa dilakukan pada industri sehingga mahasiswa memiliki bekal praktik yang baik. Design sprint dalam mata kuliah Design Thinking bertujuan: mengajarkan mahasiswa mengenai metode design sprint dengan pendekatan pembelajaran berbasis proyek yang dilakukan secara daring, meningkatkan kolaborasi dan kerjasama antar mahasiswa, terutama dalam kelompok/tim.

Dampak yang diharapkan bagi mahasiswa adalah: Mahasiswa mampu memahami teori design thinking melalui metode design sprint dengan pembelajaran berbasis proyek. Sering kali, mahasiswa mendapatkan banyak teori tanpa mendapatkan kesempatan untuk mempraktikkan secara nyata teori tersebut. Kegiatan ini mencoba untuk menjembatani antara teori dan praktek dalam perkuliahan, memberikan kesempatan bagi mahasiswa untuk bekerja sama dalam sebuah tim. Bekerja dalam tim membuat mahasiswa mempelajari softskill yang meliputi: kemampuan berkomunikasi, kemampuan menerima umpan balik, menerima keberagaman, empati, kepemimpinan, dan lain-lain.

Penelitian ini bersifat eksperimental karena menggunakan metode design sprint yang sudah terdokumentasi dan kemudian dimodifikasi untuk menyesuaikan dengan kebutuhan waktu, kelas, dan mahasiswa.

\section{Design Sprint}

Design Sprint sebagai sebuah metode baru, dikembangkan oleh Jake Knapp dari Google Ventures. Di dalam 5 hari design sprint yang ada pada hari Senin, peserta akan mulai memetakan masalah dan memilih hal-hal penting untuk difokuskan. Pada hari Selasa, peserta akan membuat sketsa solusi bersaing di atas kertas. Pada hari Rabu, peserta akan membuat keputusan sulit dan mengubah ide menjadi hipotesis yang dapat diuji. Pada hari Kamis, peserta akan membuat prototipe dengan ketelitian tinggi. Dan pada hari Jumat, Anda akan mengujinya dengan manusia nyata (Knapp, Jake, 2019).

Pengalaman bertahun-tahun Knapp, diaplikasikannya untuk mengembangkan langkahlangkah yang dapat dipraktekkan oleh perusahaan perintis pemula. Ada 6 fase dalam sebuah Design Sprint: Understand, Define, Sketch, Decice, Prototype, dan Validate.

Pada fase Understand, sesi pertama adalah Lightning Talks. Sesi ini adalah sesi yang dibawakan oleh para stakeholder atau pakar, memiliki tujuan untuk memancing ide-ide para peserta Design Sprint. Lightning Talks biasanya berlangsung selama 10-15 menit dan bisa dibawakan sampai maksimum 4 orang pembicara. Peserta yang sudah mengikuti sesi Lightning Talks bisa memasuki sesi How Might We (HMW). Pada sesi ini para peserta design sprint mulai melakukan fase memahami inti permasalahan yang dapat dibagikan dengan anggota kelompok yang lain. Sesi ini bertujuan untuk mengekspolarsi kemungkinan- kemungkinan yang bisa dilakukan oleh anggota tim dalam menghadapi sebuah permasalahan. Luaran dari sesi ini bukan pada kualitas ide tapi jumlah ide yang bisa dihasilkan oleh sebuah tim. Sesi HMW kemudian bisa dilanjutkan dengan User Journey Map untuk lebih memahami pengguna. Fase Define adalah fase selanjutnya, pada fase ini para peserta Design Sprint mulai menentukan tujuan perancangan produk/jasa. Peserta dapat memulai sesi dengan 
mendefinisikan tolok ukur keberhasilan (success metric) yang diiringi dengan menentukan tujuan, sinyal, dan cara pengukuran. Setelah tolok ukur keberhasilan sudah dibuat, tim design sprint kemudian menentukan kondisi ideal bagaimana seorang pengguna menggunakan produk atau jasa, biasanya disebut dengan User Golden Path.

Fase Sketch adalah fase ketiga dari Design Sprint. Pada fase ini, peserta design sprint mulai dapat menuangkan kreativitas dan ide pada kerta dengan cara sketsa. Cara yang lazim dilakukan pada fase ini adalah dengan mengadakan Crazy's 8 Session. Pada sesi Crazy 8 , para peserta diminta untuk membuat 8 sketsa awal selama 8 menit. Sesi ini bertujuan agar peserta dapat menuangkan ide tanpa dibatasai dengan kaidah2 desain seperti warna dan tipografi. Fase Sketch kemudian bisa disambung dengan fase keempat, yaitu: Decide. Tim menentukan melalui kesepakatan bersama keputusan-keputusan desain untuk dilanjutkan dalam tahap pembuatan purwarupa.

Fase kelima adalah prototyping atau pembuatan purwarupa. Pada fase ini tim secara mandiri dapat membuat purwarupa secara digital atau manual. Tujuan fase ini adalah menghasilkan produk/jasa yang hampir mendekati final untuk kemudian diujicobakan pada fase terakhir yakni fase validate.

\section{Pembahasan}

\section{Tahap Pengembangan}

Dalam sebuah design sprint, peserta perlu memahami tentang Design Thinking. Berpikir desain adalah metode berpikir non-linier desainer untuk memecahkan masalah. Ada 5 tahapan design thinking yaitu: empathize, define, ideate, prototyping, dan testing. Mirip dengan design sprint, proses design thinking melibatkan menghasilkan ide, membuat prototipe, dan menguji ide kepada pengguna. Sehingga penting untuk memperkenalkan design thinking terlebih dahulu kepada peserta, sebelum melakukan sebuah design sprint.

Design sprint adalah metode baru yang didirikan pada tahun 2016 dan masih relevan hingga saat ini. Sangat berguna untuk mengajari siswa cara menggunakan design sprint untuk meningkatkan pengetahuan mereka dan pada saat yang sama memiliki pengalaman dunia nyata menggunakan design sprint untuk mengatasi masalah. Mengajarkan design sprint di kelas bisa menjadi sebuah masalah yang nyata dan menyebabkan "sakit kepala" bagi dosen. Di dalam sebuah design sprint, dosen akan bertindak sebagai fasilitator sprint, atau bisa disebut juga Sprint Master. Ada beberapa masalah yang akan dihadapi dosen saat ingin melakukan design sprint:

1. Waktu yang terbatas

Design sprint adalah untuk 5 hari kerja berturut-turut tetapi kelas hanya dibatasi oleh maksimal 6 jam belajar dalam seminggu.

2. Ruang yang dibutuhkan

Di dalam melakukan design sprint yang efektif yang setiap peserta akan diminta untuk berkontribusi, dosen harus memberikan ruang yang sangat baik dan lega untuk mahasiswa dapat bekerja selama proses tersebut.

3. Fasilitas

Salah satu kunci sukses sebuah design sprint adalah menjaga energi dan motivasi siswa. Sprint yang lebih lama akan membuat mereka kelelahan sehingga makanan sehat diperlukan untuk membuat mereka tetap berenergi. Menjadi tanggung jawab dosen untuk menyediakan fasilitas sepanjang berlangsungnya design sprint, misalnya menyediakan spidol, sticky notes, dan white board untuk setiap tim.

4. Perangkat keras dan infrastruktur Pada situasi khusus, selama pandemi juga perlu mempersiapkan hardware untuk design sprint karena akan dilakukan dari jarak jauh.

Desain sprint sangat ideal untuk kelas kecil dengan sekitar 10-20 mahasiswa. Jumlah mahasiswa yang sedikit akan lebih mudah diatur oleh dosen juga dapat memberikan perhatian lebih saat kegiatan. Persiapan adalah kunci untuk melakukan design sprint yang baik. Beberapa hal yang dapat dilakukan untuk meminimalisir masalah yang mungkin akan terjadi selama design sprint, yaitu:

1. Tidak menggunakan 5 hari design sprint. Pilih yang terbaik untuk dipakai pada kelas dan sesi design sprint yang paling efektif. Fokus pada sesi yang menghasilkan ide dan prototipe, misalnya: dosen dapat memberikan penelitian yang diperlukan / awal untuk design sprint.

2. Siapkan beberapa ruangan untuk tim Anda. Tim dengan 3-4 anggota bisa melakukannya dengan sangat baik pada ukuran 3x3 meter. Satu tim membutuhkan setidaknya 1 papan tulis atau dinding lebar untuk menempelkan catatan tempel mereka. 
3. Persiapkan diri sebagai Sprint Master. Bersiap untuk hal-hal yang terjadi, menyiapkan jadwal design sprint, juga persiapkan creative brief dengan detail.

4. Siapkan perangkat lunak dan keras yang diperlukan untuk design sprint.

\section{Tahap Persiapan}

Pada minggu 1-6, mahasiswa mendapatkan teori-teori tentang design thinking dan design sprint. Teori ini untuk membekali kemampuan dan pengetahuan mahasiswa. Persiapan design sprint untuk kelas online tentu saja berbeda dengan saat persiapan untuk kelas offline. Di masa pandemi seperti ini, persiapan design sprint daring tentu saja menjadi lebih krusial. Apalagi kegiatan ini akan dilakukan secara tatap muka dalam jarak jauh. Peserta bisa berada dari mana saja. Persiapan dasar design sprint daring akan sama dengan luring. Dosen tetap perlu menyiapkan creative brief, menyusun jadwal, dan mencari pembicara sesi Lightning Talks. Saat luring dosen juga perlu mempersiapkan perangkat keras dan perangkat lunak Anda. Beberapa perangkat lunak yang digunakan selama design sprint ini adalah Google Meet (daring), Mural (daring), Jamboard (daring), dan Adobe Illustrator/ Adobe Photoshop

Di dalam design sprint kali ini, terdapat 16 mahasiswa yang terbagi dalam 4 kelompok kecil. Setiap kelompok kecil akan memiliki 1 orang pemimpin (team leader). Pemimpin tim ini yang akan membantu dosen mengkoordinasi dan mengatur hal-hal kecil di dalam kelompok. Peran team leader ini akan semakin krusial saat melakukan design sprint daring. Selain itu, dosen juga menyusun jadwal pelaksaaan design sprint dan membuat peraturan.

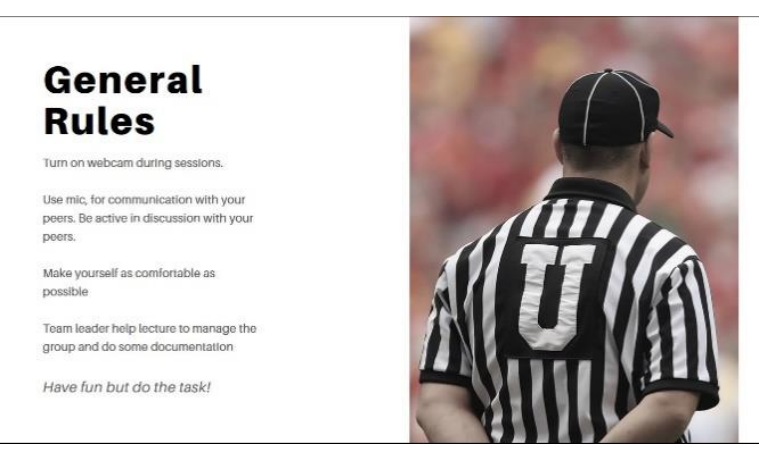

Gambar 2. Peraturan Design Sprint

Dosen juga harus menyiapkan creative brief yang detail dan mudah dipahami untuk mahasiswa. Ada baiknya creative brief diberikan beberapa hari sebelum design sprint

dimulai beserta dengan jadwal pelaksanaan design sprint. Hal ini bertujuan untuk meminimalisir waktu yang terbuang untuk melakukan briefing dan menerima sesi tanya jawab yang berkaitan dengan creative brief. Berikut ini adalah jadwal dan creative brief dari desain sprint yang diadakan. Diadakan selama 2 hari selama 180 menit masing-masing hari.

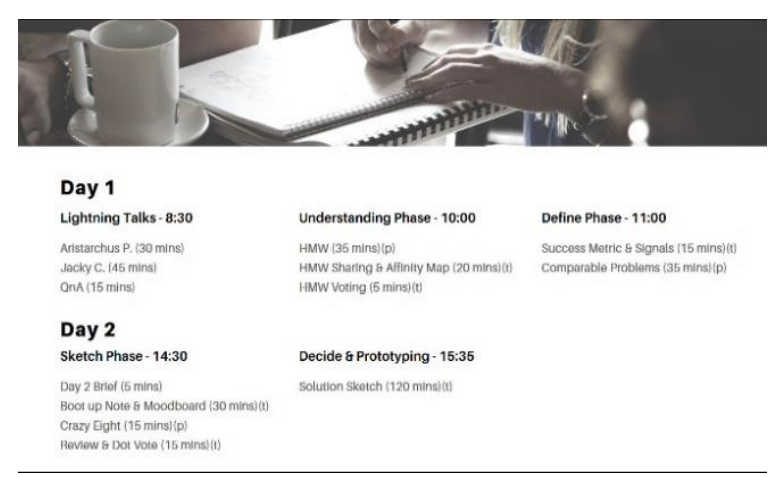

Gambar 3. Jadwal Design Sprint

\section{Problems}

Despite their effort to curb the virus, many of Indoneslans still don't adhere to thelr gutdelines The task force has been used the old way/medit to approach Indonesian, such as tolovision rad website. Their effort In digital media Is kind of lacking, other than developing a website and app. One of the problem is, they don't really empathize with many Indonessan and doesn't have a clue how to approach them empathically.

Most of the hardest hit of Covid

\section{Gambar 4. Brief Design Sprint (Tantangan dan Masalah)}

\section{Our Audience}

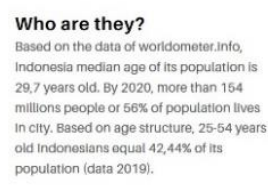

\section{Character Design}

Mandatory Must be versatlle to be Implemented on app,
animation, of other digitial medla format. Must be adhere to Indonesla's I Ideology (Pancasila), no SARA are allowed, and can help audience to feel sense of unity.

\section{Deliverable-} 3 views (front, side, quarter) \& spec she 5 basic expression poses and 1 silhouett

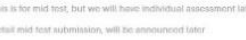

Gambar 5. Brief Design Sprint (Target Audience dan Detail Brief)
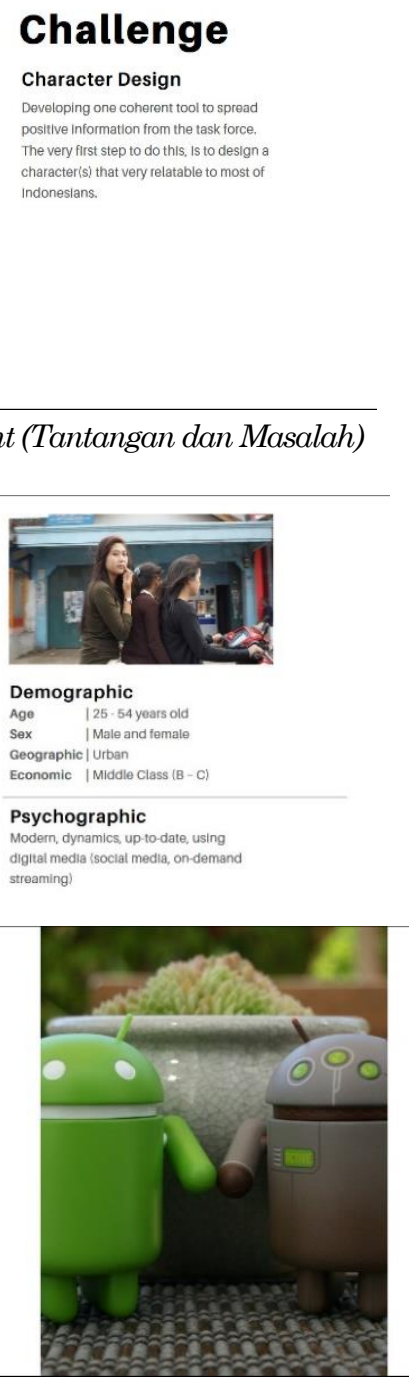


\section{Tahap Pelaksanaan}

Kegiatan ini dilaksanakan pada hari Rabu, 30 September 2020; dan Kamis, 1 Oktober 2020 di dalam jam perkulihaan MK. Design Thinking. Design sprint hari pertama dimulai tepat jam 8:30 dengan dua sesi lightning talks yang dibawakan oleh Aristarchus P. K., dan Jacky Cahyadi. Tema yang diangkat dan dibahas pada sesi ini adalah Character Design dan Animation Pipeline.

Sesi lightning talk, adalah sebuah sesi dalam design sprint untuk memancing ide-ide peserta design sprint. Umumnya sesi ini berlangsung selama 15 menit.

Sesi lightning talks diakhiri dengan pertanyaan dari mahasiswa mengenai materi yang telah dibawakan. Peserta design sprint antusias melemparkan pertanyaan kepada kedua pembicara sesi. Materi yang cukup banyak membuat waktu pelaksanaan pada sesi ini lebih dari jadwal yang ditentukan.
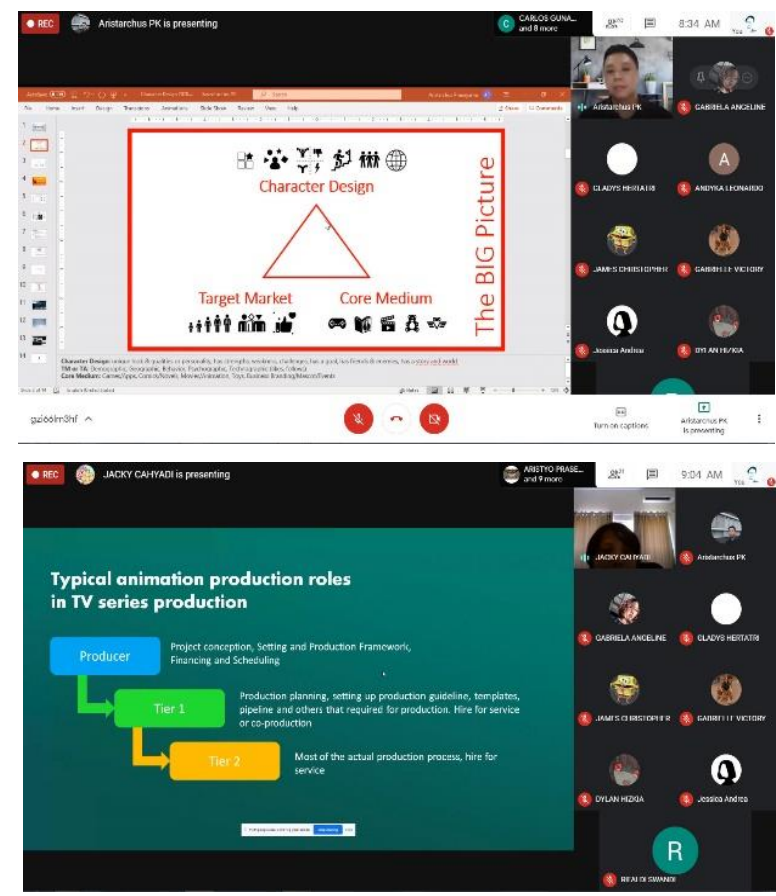

Gambar 6. Sesi Lightning Talks

Begitu sesi selesai, mahasiswa langsung dibagi dan join ke dalam tautan per kelompok yang sudah terlebih dahulu disiapkan oleh dosen. Selama pelaksanaan, setiap kelompok mendapatkan 1 tautan Google Meet, 1 tautan Mural/Jamboard (online whiteboard). Sesi dilanjutkan dengan sesi HMW (How Might We). Sesi ini, mahasiswa diminta untuk berpikir kreatif (brainstorming) untuk memecahkan masalah yang ada pada creative brief. Setiap mahasiswa diminta berkontribusi ide-ide dalam tim. Pada sesi ini yang paling penting bukan pada kualitas ide yang disampaikan tetapi lebih ke arah jumlah ide yang bisa dikeluarkan. Ide-ide tersebut kemudian akan divoting/ditentukan untuk ke proses selanjutnya. Sesi HMW ini berjalan selama 1,5 jam.

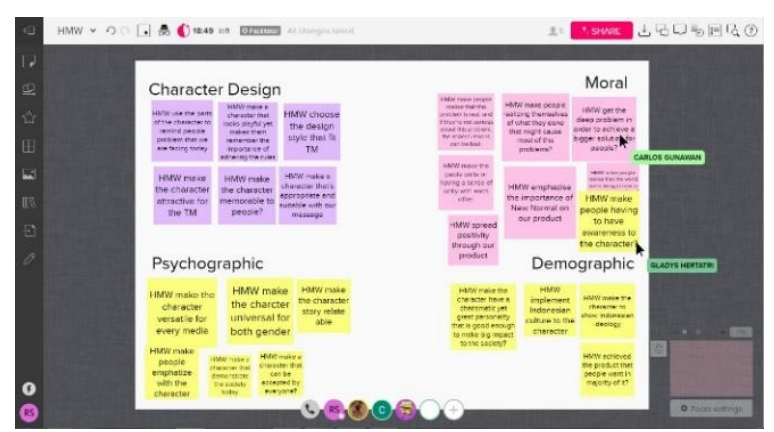

Gambar 7. Sesi How Might We

Sesi selanjutnya, adalah menentukan success metric and signals. Dalam kelompok, mereka diminta untuk menentukan indikator kesuksesan dari solusi mereka. Hal ini penting untuk dilakukan agar saat melakukan testing, tiap tim memiliki sebuah patokan terukur untuk melihat tingkat sukses dari solusi yang telah mereka buat. Sesi ini berjalan berurutan dengan sesi Comparable Problems. Dalam sesi ini, peserta dalam diminta untuk melihat halhal yang sudah/telah dilakukan oleh kompetitor berkaitan dengan solusi yang telah mereka buat sehingga mereka bisa membandingkan dengan hal yang pernah dibuat. Design sprint hari pertama selesai jam 11:45, ditutup dengan brief ulang untuk membahas hal-hal yang harus dilakukan keesokan hari (hari kedua).

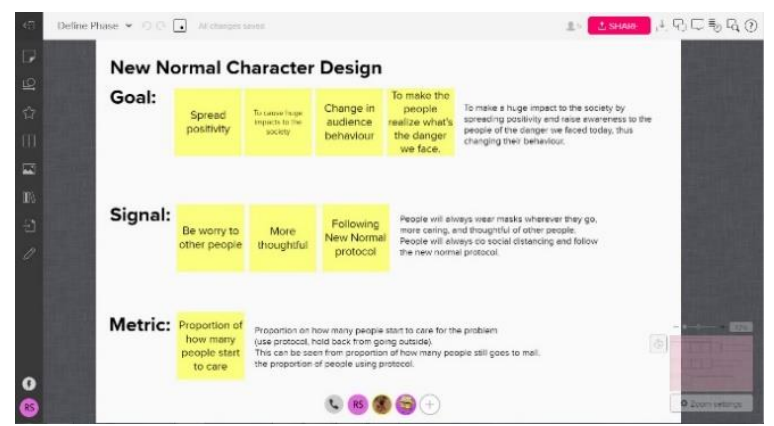

Gambar 8. Sesi Success Metric \& Signals

Hari kedua design sprint dimulai pada jam 14:30, mahasiswa diminta kumpul kembali lebih awal untuk melakukan briefing singkat. Sesi pertama di hari ini adalah Boot Up Note Taking, pada sesi ini setiap tim diminta untuk melihat ulang (review) hal-hal yang sudah dilakukan pada hari sebelumnya. Jika ada halhal yang belum diselesaikan, mereka masih 
bisa menyelesaikan dan melengkapi pada sesi ini.

Sesi kemudian dilanjutkan dengan membuat moodboard. Moodboard dibuat secara berkelompok bukan individu, sehingga mengharuskan mahasiswa untuk berdiskusi. Moodboard berisikan gambar-gambar sebagai referensi yang akan mereka gunakan nanti pada sesi Crazy Eights. Kedua sesi ini berlangsung selama 1 jam.

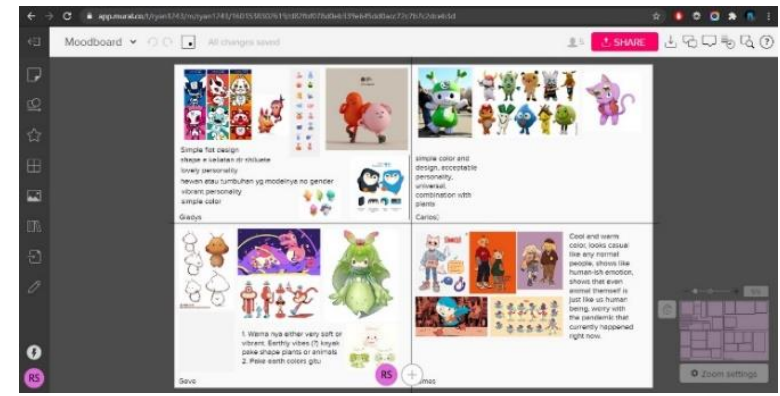

Gambar 9. Moodboard

Setelah kedua sesi di atas selesai, setiap tim melakukan sesi Crazy Eights. Sesi Crazy Eights adalah sesi untuk membuat iterasi awal dari sebuah desain. Sesi ini sifatnya individual, sehingga setiap peserta harus memiliki kontribusi desain awal untuk kemudian dibahas dan didiskusikan. Pada sesi ini setiap peserta diminta membuat 8 kotak yang nantinya akan diisi sketsa kasar. Peserta hanya memiliki waktu 8 menit untuk membuat sketsa kasar tersebut. Hal penting dari sesi ini adalah tidak melihat kualitas gambar melainkan pada ide yang tergambarkan/tersampaikan. Setiap kelompok bisa melakukan beberapa ronde crazy eights jika dirasa perlu.

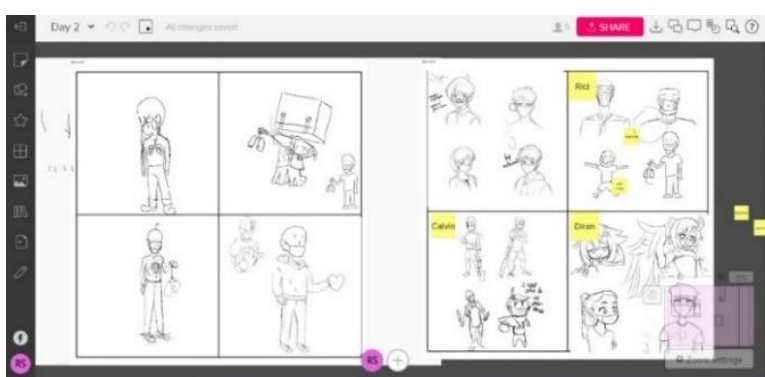

Gambar 10. Sesi Crazy Eights

Jika kelompok sudah puas dengan sesi crazy eights yang sudah dilakukan, mereka bisa melanjutkan dengan presentasi hasil dari crazy eights tersebut dan melakukan voting. Hasil voting, bisa dilanjutkan dan diperbaiki sampai sesuai dengan hasil akhir yang diminta/tercantum pada creative brief.
Hari kedua design sprint diakhiri pada jam 17:35, setiap tim sudah melakukan sketsa kasar dan memiliki sebuah solusi. Penghalusan karya desain dilakukan di luar jam design sprint. Seminggu setelah design sprint berakhir, setiap kelompok bisa menyerahkan sketsa hasil akhir kepada dosen untuk kemudian didiskusikan. Selama seminggu, mahasiswa melakukan fase decide secara mandiri dengan kelompok masing-masing.

Secara sederhana design sprint yang telah dilakukan dalam mata kuliah ini memiliki alur sebagai berikut:

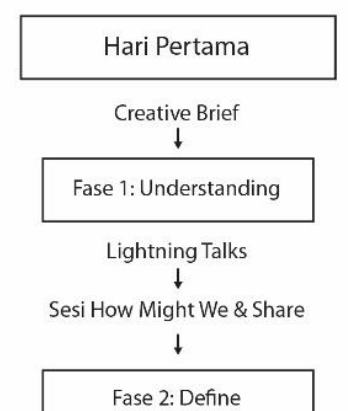

Menentukan Success Metric

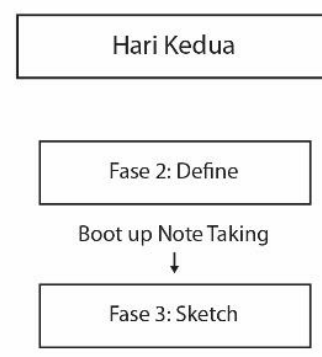

Comparable Problems $\downarrow$

Crazy's Eight Sketch
Gambar 11. Alur Design Sprint yang Dilakukan.
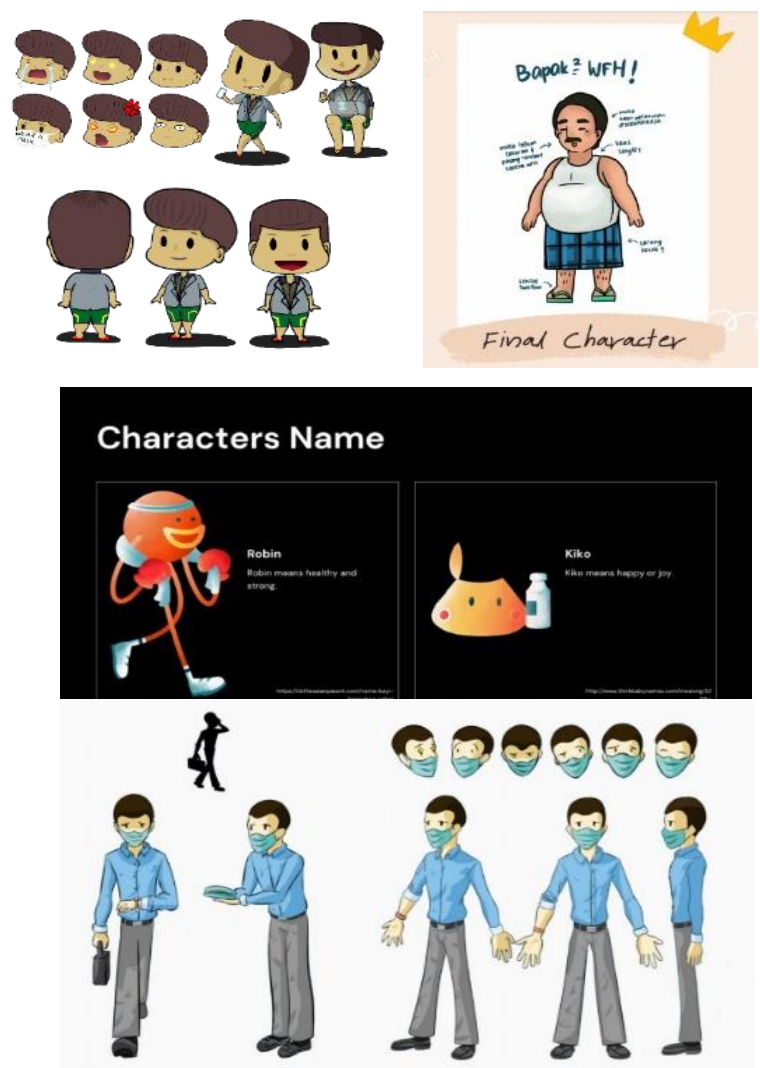

Gambar 12. Hasil Design Sprint 
Berikut ini adalah hasil dari design sprint yang telah dilakukan mahasiswa. Nantinya hasil design sprint ini bisa diujicobakan kepada target audience dan kemudian dievaluasi dan dilakukan perbaikan.

\section{Umpan Balik dan Analisis}

Seminggu setelah design sprint, diadakan evaluasi terhadap kegiatan yang sudah dilakukan. Mahasiswa diminta membuat laporan singkat pengalaman dan pendapat mereka tentang design sprint yang sudah dilakukan. Berikut ini adalah umpan balik dari setiap pemimpin tim.

So far, I am happy on what my team had achieved and done in this Design Sprint work. Our results quite reached what we had initially hoped, and I am glad. As the leader, I tried to make my teammates work without much in mind so I tried to divide the work and with each result we try to evaluate what needs to be reworked or if its good enough,... (Jacaranda, 2020).

Bagi Amadeus, design sprint yang ia lakukan bersama kelompoknya melebihi ekspektasinya. Tugasnya sebagai seorang ketua adalah mendelegasikan pekerjaan kepada anggota tim dan memimpin evaluasi selama proses kegiatan berlangsung.

Overall, the design sprint is really important to do for group working. Because, for me this is really helpful. We do not need to think by ourselves about what should we draw or design, but we can share with others about our ideas (Chenliasa, 2020).

Nethania berpendapat bahwa design sprint sangat penting dalam kaitannya dengan kerja sama dalam sebuah kelompok. Cara ini sangat berguna karena sebuah permasalahan tidak hanya diselesaikan oleh individu namun bisa diselesaikan dalam kelompok.

Overall, our member is well balanced and active. At first, we are a little bit shy of having interaction after a long period of not meeting each other over online class. But as times goes by the member become more actives. Even after the 2 days of Design Sprint end, our members are easy to contact to help built the final product (Hertatri, 2020).

Gladys berpendapat, kegiatan ini bisa ia ikuti dengan baik bersama dengan kelompoknya. Design sprint membuat setiap anggota kelompok menjadi aktif dan berkontribusi dalam mencari ide pemecahan sebuah masalah.

We learn a lot from this Lecture and maybe in the future we can have more organized Design Sprint... more improvement is needed especially on the Communication...for me that..is also primary reason for team to success (Hizkia, 2020).

Komunikasi adalah kunci, demikian yang Dylan Hizkia sampaikan mengenai design sprint. Kesuksesan sebuah tim dalam sebuah design sprint bergantung pada komunikasi yang lancar antar anggota kelompok.

Berkaitan dengan perangkat lunak daring yang digunakan. Kegiatan dilakukan secara daring dengan menggunakan Google Meet sebagai platform komunikasi dan Mural sebagai media papan tulis daring. Dari hasil evaluasi, para peserta lebih memilih untuk menggunakan Mural saat berdiskusi dalam tim. Awalnya, 2 kelompok menggunakan Mural dan 2 kelompok menggunakan Jamboard namun ada 1 kelompok yang memutuskan untuk berpindah ke Mural di tengah sesi. "Jamboard is nice for the formal discussion, with the sticky note feature and more private working space, but Mural is far more better, same features but giving more feels of a design sprint with the one super big working space," (Hizkia, 2020) seperti yang disampaikan oleh salah seorang peserta selama jalannya design sprint. Banyaknya fitur pada Mural menjadi alasan peserta untuk menggunakan Mural daripada Jamboard.

Secara umum design sprint berjalan dengan lancar selama 2 hari. Beberapa mahasiswa berharap metode ini bisa lebih sering dilakukan. "Thats just it I wish we can have more assignment just Like this...” (Hizkia, 2020).

Beberapa masalah yang timbul selama design sprint, ada pun hal-hal yang perlu dicatat pada pelaksanaan design sprint online ini adalah: Pertama; awalnya, cukup dikuatirkan kondisi mahasiswa yang "ogah-ogahan" melakukan kegiatan ini karena durasi yang cukup panjang. Faktanya, mahasiswa bisa bekerja secara mandiri di dalam tim dan berkontribusi ide-ide saat sesi brainstorming.

Kedua, koneksi internet menjadi masalah yang signifikan, ada 1 kelompok yang hampir semua anggota tim-nya mengalami kesulitan koneksi 
internet sehingga proses diskusi tidak dilakukan secara verbal online, melainkan melalui WA chat. Sprint Master juga tidak luput mengalami permasalahan koneksi, koneksi di hari pertama sempat mati selama 15-20 menit.

Ketiga berkaitan dengan ketepatan waktu menjadi masalah pada awal sesi di hari pertama. Banyaknya materi yang disampaikan oleh pembicara Lightning Talks membuat waktu menjadi mundur 45 menit dari jadwal yang telah ditentukan. Akibatnya, ada durasi sesi yang terpaksa harus dikurangi.

(in HMW Session)... Working without a proper time keeper is quite hard because often we end up stretching the time allocated for a particular task, this makes the brainstorming process for solution creation less effective (Andrew, 2020).

Sprint Master juga perlu memperhatikan perannya sebagai time keeper. Sebagai seorang time keeper, sprint master harus lebih disiplin dan tegas dalam manajemen waktu sehingga sprint dapat berjalan dengan efisien.

But I must admit it was really awkward having one teammate act as silent reader, since we mostly using the WA group chat to communicate, where I think it's the biggest trouble in this sprint. The silent reader did everything that should be done in the steps, but the informal discussion part went pretty weird and it's like the other member can't know what he has in his mind or whether he had something to add or comment about the discussed topic (Arletta, 2020).

Berdasarkan umpan balik dari Arletta, masalah keempat adalah menghindari silent reader dalam sebuah tim. Pada desain sprint berikutnya disarankan tidak menggunakan komunikasi yang berbasis teks namun mewajibkan mahasiswa untuk minimal, open mic. Bahkan jika memungkinkan bisa dilakukan open camera. Berdasarkan pengamatan selama proses design sprint, tim yang melakukan sesi dengan open camera memiliki sesi diskusi yang lebih hidup.

Berdasarkan umpan balik yang disampaikan para peserta design sprint, dapat disimpulkan bahwa design sprint adalah metode yang menarik dan efektif digunakan untuk bekerja sama dalam kelompok. Hambatan seperti rasa malu, tetap ada, dan biasanya hanya terjadi pada sesi awal saja. Pembagian kerja perlu dilakukan agar tim dapat berjalan dengan efektif. "This sprint has been a quite refreshing and fun experience in the midst online class." (Andrea, 2020).

\section{Simpulan}

Design sprint yang dilakukan pada mata kuliah ini berakhir dengan memuaskan. Setiap tim dapat mencapai target luaran yang diminta dan anggota tim bisa berkolaborasi dengan baik.

Dari kegiatan ini bisa disimpulkan bahwa metode design sprint yang dipakai dapat digunakan sebagai kerangka kerja untuk mengaplikasikan teori design thinking melalui pembelajaran berbasis proyek yang sarat unsur kerjasama.

Tahap persiapan design sprint, merupakan fase penting untuk mencapai design sprint yang sukses. Secara garis besar yang dilakukan mahasiswa adalah hari pertama design sprint, setiap tim berfokus kepada pemecahan masalah dengan melakukan brainstorming dan membuat berbagai keputusan desain. Hari kedua design sprint, mahasiswa membandingkan solusi yang sudah dipikirkan pada hari pertama dan membuat sketsa dari solusi yang sudah mereka pikirkan.

Pada masa mendatang, design sprint daring bisa dilakukan dengan beberapa perbaikan yang meliputi membuat dokumentasi dan modul yang terdesain dengan baik oleh desainer, sebagai pegangan dosen untuk melakukan design sprint pada masa mendatang. Pada masa mendatang diharapkan bisa fokus kepada understanding phase atau testing phase. Pada fase understanding phase dengan mendatangkan user ke dalam kelas sehingga mahasiswa dapat secara langsung melakukan fase empathize. Sedangkan fase testing phase, mahasiswa bisa diminta untuk bekerja di lapangan untuk melakukan ujicoba terhadap prototype yang sudah dibuat. Tentunya dengan pengawasan dari dosen.

\section{Daftar Pustaka}

Andrea, J. (2020, 12). Umpan Balik Jessica. (R. P. Sutanto, Interviewer)

Andrew, C. (2020, 12). Umpan Balik Calvin. (R. P. Sutanto, Interviewer)

Arletta. (2020, 12). Umpan Balik Arletta. (R. P. Sutanto, Interviewer)

Canedo, E. D., \& Ferreira, V. G. (2019, March 29). Design Sprint in Classroom: Exploring New 
Active Learning Tools. Journal of Ambient Intelligence and Humanized Computing. doi:https://doi.org/10.1007/s12652-01901285-3

Chenliasa, N. (2020, 12). Umpam Balik Nethania. (R. P. Sutanto, Interviewer)

Hertatri, G. (2020, 12). Umpan Balik Gladys. (R. P. Sutanto, Interviewer)

Hizkia, D. (2020, 12). Umpan Balik Dylan. (R. P. Sutanto, Interviewer)

Jacaranda, A. (2020, 12). Umpan Balik Amadeus. (R. P. Sutanto, Interviewer)
Knapp, Jake. (2019). The Design Sprint - GV. Retrieved August 2020, from Google Ventures: https://www.gv.com/sprint/

What is Design Thinking | Interaction Design Foundation. (2019). Retrieved August 2020, from UX Design Courses \& Global UX Community | InteractionDesign Foundation: ttps://www.interactiondesign.org/literature/topics/designthinking\#: :text=Design\%20thinking\%20is $\% 20 \mathrm{a} \% 20$ non,are $\% 20$ ill $\% 2$ Ddefined $\% 20$ or $\%$ 20unknown. 